\title{
Optimizing urothelial cell preparation for the human urinary micronucleus assay.
}

Fortin $\mathrm{F}^{\mathrm{a}, \mathrm{b}, \mathrm{c}}$, Anghel $\mathrm{T}^{\mathrm{a}}$, Brochu $\mathrm{P}^{\mathrm{a}, \mathrm{b}}$, and Lemieux $\mathrm{N}^{\mathrm{a}, \mathrm{b}, \mathrm{c}, *}$

a Département de pathologie et biologie cellulaire; Université de Montréal, C.P. 6128, Succursale

Centre-ville, Montréal, Québec, Canada, H3C 3J7; and

${ }^{\mathrm{b}}$ Département de pathologie;

${ }^{\text {c }}$ Centre de recherche, Centre Hospitalier Universitaire Sainte-Justine, 3175, chemin de la Côte-SainteCatherine, Montréal, Québec, Canada, H3T 1 C5.

* To whom correspondance should be addressed at Université de Montréal, Département de pathologie et biologie cellulaire, C.P. 6128, Succursale Centre-ville, Montréal, Québec, Canada, H3C 3J7. Phone : +1 514-343-6309. Fax: +1 514-343-5755. E-mail: nicole.lemieux@umontreal.ca.

Short title: Optimizing urinary micronucleus test

E-mail addresses

F Fortin: flechere.fortin@umontreal.ca

T Anghel: anghel.tiberiu@gmail.com

P Brochu: pierre_brochu@ssss.gouv.qc.ca

N Lemieux: nicole.lemieux@umontreal.ca

Cet article a été accepté pour publication le 17 mai 2010, dans le journal Toxicology in Vitro. La référence complète de cet article est :

Fortin F, Anghel T, Brochu P, Lemieux N. Optimizing urothelial cell preparation for the human urinary micronucleus assay. Toxicology in Vitro (2010), doi: 10.1016/j.tiv.2010.05.011

La version électronique de cet article est disponible chez l’éditeur sur le site internet :

http://dx.doi.org/10.1016/j.tiv.2010.05.011 


\section{Abstract}

Biological monitoring of early genotoxic effects in urothelial cells using the urinary micronucleus (MNu) assay is promising for early detection of cancer, such as bladder carcinoma. But many problems are encountered, the major being the poorly differential staining of cells, particularly in women having an important amount of squamous cells. We have optimized the protocol and obtained a differential staining of the cell types present in urine on 10 subjects. Following Carnoy I fixation and Papanicolaou staining, urothelial cells were blue while most squamous cells were pink. This differential staining allowed for optimization of the MNu assay on a single urine void, for both females and males. Even if our MNu means were comparable to the literature, the great variation in reported MNu results could reside in the ability of scorers to distinguish correctly between urothelial and squamous cells. When monitoring exposed populations, this erroneous distinction could largely influence the results, even more in women's urine samples. Given a situation where exposure would not increase micronuclei frequency in vaginal squamous cells, their erroneous analysis in the $\mathrm{MNu}$ assay could mask an early genotoxic effect. Therefore, as transitional cell carcinoma of the bladder originates from transformed urothelial cells, restricting micronuclei analysis to urothelial cells could yield a more precise estimate of cancer risk in exposed populations. Moreover, it is hoped that the improvements proposed in this paper will allow for an easier implementation of the $\mathrm{MNu}$ assay in various set-ups and enhance its specificity, since MNu are considered a suitable biomarker.

\section{Keywords}

Micronuclei, Urine, Urothelial cells, Papanicolaou staining, Biological monitoring, Bladder cancer. 


\section{Introduction}

Bladder cancer has been associated with exposure to chemicals present in environmental and occupational settings, such as arsenic in drinking water (Basu et al., 2002), 4,4'-methylenebis-(2chloroaniline) used in manufacturing of wear-resistant polyurethane products (Murray and Edwards, 1999) or occupational exposure as a painter (Straif et al., 2007). In particular, exposure to polycyclic aromatic hydrocarbons (PAHs) present in coal gasification and aluminium production industries, in mixtures of coal-tar pitch, coal tar and asphalt (Straif et al., 2005), as well as in tobacco smoke (Burgaz et al., 1995; DeMarini, 2004), reveal a statistically significant excess risk of bladder cancer. Urothelial carcinoma (or transitional cell carcinoma) is the most common form of bladder cancer, representing $90 \%$ of bladder tumors. Urothelial carcinoma can arise in every part of the urinary tract, from ureters to urethra, although bladder is the most common site. Being frequently present on multiple sites, this tumor is thought to arise following the action of carcinogens on the urinary tract and subsequent neoplastic transformation of the bladder epithelium cells (McKee, 2003).

The normal bladder epithelium, called urothelium, is lined with superficial cells, known as umbrella cells. These are often large binucleated or larger multinucleated cells, covering several layers of deeper (cuboidal) urothelial cells, formerly known as transitional cells. Cuboidal urothelial cells are smaller than the umbrella cells, with a single nucleus, and show little variation in size. They are attached to each other and to the umbrella cells with numerous desmosomes. In voided urine, many epithelial cell types can be found: umbrella cells, cuboidal urothelial cells (occurring singly or in cluster), squamous cells, and renal tubular cells. In males, squamous cells are not frequent and are of urethral origin. More abundant in females, squamous cells originate either from the trigone of the bladder or from the vagina, through contamination of the urine with vaginal fluid (Koss and Melamed, 2005b; McKee, 2003). In addition, squamous cell types of the urine vary, according to the hormonal status of the women. Superficial and intermediate squamous cells are found in urine samples taken 
from women in childbearing age, while navicular (with glycogen deposits) and parabasal (which are the progenitor cells) squamous cells will exfoliate only during specific hormonal conditions such as pregnancy, breastfeeding period, menopause or progesterone hormone therapy (Koss and Melamed, 2005c).

Urinary cytology on voided specimen has been used for long term follow-up of industrial workers exposed to a bladder carcinogen ( $p$-aminodiphenyl), but has failed in the detection of lowgrade tumors. Only high-grade urothelial tumors and flat carcinoma in situ of the bladder could be readily detected, suggesting that these cancers were not preceded by a precursor (dysplastic) stage detectable with urinary cytology on voided specimens (Koss and Melamed, 2005d). Nevertheless, it is expected that monitoring for early biological effects occurring prior to neoplastic transformation of urothelial cells could be done on the target tissue, by using the urinary micronucleus ( $\mathrm{MNu}$ ) assay. Following arsenic exposure through drinking of contaminated water, an increase $\mathrm{MNu}$ frequency was observed in populations living in many countries, including India, Chile, China and United States (Basu et al., 2002; Biggs et al., 1997; Tian et al., 2001; Warner et al., 1994). Also, a follow-up study revealed a decreased frequency of $\mathrm{MNu}$ in individuals who lowered their intake of water contaminated with arsenic (Moore et al., 1997a), suggesting the usefulness of this urinary assay in environmental health. Since then, many groups have used the MNu assay to perform biological monitoring of individuals living in $\mathrm{Cs}^{137}$ radionuclide-contaminated regions (Jen et al., 2002), as well as in workers exposed to various chemicals, such as 4,4'-methylenebis-(2-chloroaniline) (Murray and Edwards, 1999), sodium nitrite and $n$-phenyl-1-naphtylamine (Fontana et al., 2001). Workers exposed to PAHs through bitumen fumes and emanations from coke ovens have also been monitored for increased micronuclei frequency in urothelial cells (Murray and Edwards, 2005; van Delft et al., 2001). Thus, MNu assay is considered to be a suitable biomarker of bladder cancer risk (Majer et al., 2001). Still, many problems are encountered, making interpretation of the $\mathrm{MNu}$ assay difficult: 
insufficient number of analysable cells in the preparation (Rosin and Anwar, 1992; Tian et al., 2001; van Delft et al., 2001), or contamination of the urine sample with bacteria or fungi (Basu et al., 2004). This led to the collection of many urine specimens for a given subject (Basu et al., 2004; Fontana et al., 2001; Moore et al., 1997b), or to a low success rate (45 - $60 \%$ ) for this technique in some studies (Rosin and Anwar, 1992; van Delft et al., 2001). In addition, the presence in women's urine sample of a large number of undesired squamous cells, that are difficult to differentiate with urothelial cells (Warner et al., 1994), limits biological monitoring, in comparison to male populations (Moore et al., 1997b). To get rid of the squamous cells problem, enrichment in urothelial cells from female urine sediments using magnetic cell sorting has been described (Dorrenhaus et al., 2007), but this technique seems limited to biochemical applications. At the moment, as no other developments in the MNu assay have been described to allow suitable preparation of urothelial cells, excellent urine specimens and a very good cytological knowledge are necessary for analysis (Espinoza et al., 2008).

In order to address these issues, our objectives were to optimize the sample collection for women and men, and obtain a differential staining between urothelial and squamous cells. To do so, we compared two commonly used fixatives, methanol (Dorrenhaus et al., 2007; Titenko-Holland et al., 1994) and Carnoy I (Ghosh et al., 2006; Jen et al., 2002), as well as two staining methods, Giemsa (Ghosh et al., 2006; van Delft et al., 2001) and the Papanicolaou technique (Koss and Melamed, 2005a). Giemsa is used to produce high-quality staining of the chromatin and nuclear membrane of all cell types (Barcia, 2007), while Papanicolaou is commonly used in urinary cytology for diagnostic of high-grade urothelial tumors (Koss and Melamed, 2005d; McKee, 2003).

\section{Materials and Methods}

\section{Subjects}

5 females and 5 males, aged between 20 and 60 years, were selected. All were healthy non- 
smokers, with no history of abnormal urinary cytology, bladder cancer or any other cancer. Three of the women were using contraceptive pills (21, 26 and 34 years), while the other two were in early post-menopause (51 and 58 years). This research was approved by the research ethical board of our institutions and all subjects provided informed consent to participate in this study.

\section{Collection of urine specimens}

A midstream clean catch collection of urine from the second or third voids of the day was requested from the subjects (Koss and Melamed, 2005b). Before urine collection, participants were asked to wash extensively their urethral area, including the labiae in women, with flushable premoistened wipes, and to void the first portion of the urine stream into the toilet. The midstream urine was then collected in sterile containers. These procedures were adopted to limit the contamination of urine with squamous cells coming from vaginal fluids of female, as well as to limit the microbial contamination of urine from both sexes. Midstream urine was processed within $2 \mathrm{~h}$. Volume of voided specimens varied from $50 \mathrm{ml}$ and $250 \mathrm{ml}$; several trials were done to determine the best sample volume for female and male. Some male subjects were required to raise their hydration level by drinking one glass of water (approximately $250 \mathrm{ml}$ ) every 30 minutes, for 3 hours before the void, in order to increase the amount of desquamated urothelial cells in urine (Koss and Melamed, 2005b).

\section{Isolation of exfoliated cells in urine}

As urine of males contains considerably less cells than urine of females, we modified the isolation procedure of Lehucher-Michel et al. (1996) to minimize cell loss. Urine samples were first centrifuged at $400 \times \mathrm{g}$ for $10 \mathrm{~min}$ in $250 \mathrm{ml}$ centrifuge plastic bottle (Fisher Scientific Company, Ottawa, On, Canada). The supernatant was carefully discarded, leaving 10 to $15 \mathrm{ml}$ urine in the bottle. 
The pellet was resuspended and transferred to a $15 \mathrm{ml}$ conical centrifuge tube (Sarstedt inc., Montreal, QC, Canada). A second centrifugation was performed at $400 \times \mathrm{g}$ for $10 \mathrm{~min}$. The supernatant was again discarded, leaving $0.5 \mathrm{ml}$ to ensure no cell loss, especially in urine samples from males. The cell pellet was washed with $10 \mathrm{ml}$ sterile $\mathrm{NaCl} 0.9 \%$ and centrifuged at $400 \times \mathrm{g}$ for $10 \mathrm{~min}$. At this step, half the samples of both females and males, presented a cloudy material stacked on top of the cell pellet. The material, present in the supernatant, was separated and processed further in the same way as the cell pellet. Microscopic observation of the cloudy material revealed that there were no well preserved urothelial cells in this fraction. It mostly contained well preserved squamous cells, some neutrophils and cellular debris; this material was therefore discarded. After a second wash, the final pellet was resuspended in $1.0 \mathrm{ml}$ sterile $\mathrm{NaCl} 0.9 \%$. For samples from males, the pellet was transferred in a $1.5 \mathrm{ml}$ microtube, and further centrifuged at $10000 \times \mathrm{g}$ for 1 minute. Most of the supernatant was removed and the pellet was resuspended in $0.2 \mathrm{ml}$ sterile $\mathrm{NaCl} 0.9 \%$. The final volumes obtained after cell isolation for female and male samples ( 1 and $0.2 \mathrm{ml}$ respectively) reflect the differences in the size of the cell pellets.

\section{Fixation and staining of exfoliated cells in urine}

Different combinations of fixatives and staining were used during the optimization process. Fixation was performed using either $100 \%$ methanol (Fisher Scientific Company) or Carnoy I fixative (methanol:glacial acetic acid, 3:1; Fisher Scientific Company). Pellets were resuspended in the fixative and fixed twice (10 $\mathrm{ml}$ for female; $1.5 \mathrm{ml}$ for male) for 10 minutes. After fixation, pellets were resuspended in $0.5 \mathrm{ml}$ (female) or $25 \mu \mathrm{l}$ (male) fixative. One cell spread on precleaned microscope slide (Fisher Scientific Company) was prepared for each female and male sample. Slides were air dried overnight and staining was performed, using Giemsa or Papanicolaou.

Giemsa staining was realized with freshly filtered 4\% Giemsa diluted in Gurr's pH 6.8 buffer 
(both from Invitrogen, Burlington, ON, Canada). The Papanicolaou technique was done according to Koss and Melamed (2005a) using a DRS-601 automatic slide stainer (Sakura Finetek USA, inc., Torrance, CA, USA). Briefly, slides were stained in Harris hematoxylin (ACP Chemicals inc., Montreal, QC, Canada). A differential extraction of the hematoxylin with $0.25 \% \mathrm{HCl}$ (Fisher Scientific Company) was done before dehydration and followed by a subsequent cytoplasmic staining with orange G (OG-6; ACP Chemicals inc.) and eosin (EA-65; VWR International, Mississauga, ON, Canada). Slides were then conditioned in xylene (Fisher Scientific Company) and mounted using a Tissue-Tek coverslipper (Sakura Finetek USA, inc.).

\section{Micronuclei scoring procedure and criteria}

Following optimization of isolation and differential coloration of the exfoliated cells, the $\mathrm{MNu}$ assay was performed on samples obtained from the 10 participants. Slides were screened at $400 \times$ magnification on a Leica Laborlux microscope (Leica Microsystems Canada inc., Richmond Hill, ON, Canada) and only cells with an intact nucleus that were not clumping or overlapping, were chosen. Micronuclei were scored following a modification of the Fenech (2007) and Reali (1987) criteria, as urothelial cells frequently contain cytoplasmic inclusions (Koss and Melamed, 2005b) that can be mistaken for micronuclei. These criteria were: (a) being less than 1/3 and more than 1/16 diameter than the main nucleus, (b) being on the same focus plane, while (c) not superimposing to the main nucleus, (d) having the same color, texture and refraction as the main nucleus, (e) having a smooth round or oval shape, and (f) having limits clearly distinguishable from the main nuclear membrane if touching the main nucleus. Inclusions are usually smaller (less than 1/16 diameter) and mostly on a different focus plane than the main nucleus. 1000 urothelial cells were analyzed at 1000× magnification, for the presence of micronuclei. All micronuclei were confirmed by a second observer. Microphotographs were obtained with a SPOT RT color camera, using the SPOT imaging software, 
version 4.1 (Diagnostic Instruments inc., Sterling Heights, MI, USA).

\section{Results}

\section{Collection and isolation of exfoliated cells}

In general, an efficient isolation of urothelial cells present in urine samples from both the females and the males could be readily performed. For males, a minimum urine specimen of $250 \mathrm{ml}$ was required. One male needed to provide a new urine specimen so that 1000 cells could be analysed in a single sample. Finally, another male subject was excluded and replaced, as his urine samples provided only a few urothelial cells, even after hydration was augmented.

As for the women, a urine specimen of $100 \mathrm{ml}$ provided enough urothelial cells to perform the MNu assay. Two females were asked to wash more thoroughly their labiae and urethral area before providing a second urine specimen, in order to reduce contamination with bacteria or fungi, and the number of squamous cells. Indeed, the squamous cells represented more than $95 \%$ of the cells present in their samples. The midstream clean catch collection of urine, as well as the careful cleaning of urethral region, clearly reduced the amount of bacteria and squamous cells in urine samples of females.

\section{Fixation and staining of exfoliated cells}

When Giemsa or Papanicolaou staining were done after methanol fixation (Fig. 1A and B, respectively), this resulted in a loss of morphological features: urothelial cells $(U)$ were roundish, with their nucleus nearly black and not clearly delineated. Squamous cells (S) and urothelial cells were blue, their nucleus barely visible and the cytoplasm of urothelial cells being darker than that of squamous cells. With Carnoy I fixation and Giemsa staining (Fig. 1C), squamous and urothelial cells presented the same violet color. Urothelial cells were again roundish, their cytoplasm was not sharply 
demarcated, and the nucleus, again, was not clearly delineated.

Carnoy I fixation followed by the Papanicolaou technique provided the best results (Fig. 1D to F). A differential staining was achieved, as most of the squamous cells appeared red to pink, while the urothelial cells were light blue. Furthermore, in women's urine samples, we could determine that blue cuboidal urothelial cells represented 5 to $10 \%$ of the cells, compared to 90 to $95 \%$ of squamous cells, of which $83 \%$ were pink superficial squamous cells, while $17 \%$ were blue intermediate ones. Table 1 summarizes the main morphological features of urothelial and squamous cells. Morphology of urothelial cells was well preserved with a sharply demarcated cytoplasm, and a dark blue nucleus clearly delineated presenting chromatin textures. The size of the nucleus was big when compared to the size of the cell (nuclear-cytoplasmic ratio is around 1:2 to 1:5). In urothelial cell clusters, desmosomal attachment points (small arrows in Fig. 1D) led to a cytoplasm stretching. Occasionally, blue intermediate squamous cells (I) originating either from the vagina or the trigone (Fig. 1F) could be found, but were much larger in size than cuboidal urothelial cells. More rarely, some of these intermediate cells called navicular cells, also showed yellowish glycogen deposits. Another distinctive feature of the vaginal squamous cells is the presence of bacilli-type bacteria on their cytoplasm.

\section{Micronuclei analysis in urothelial cells}

Usually, enough urothelial cells were present on one slide per subject to perform the MN analysis. MN analysis was performed only on "blue” cuboidal urothelial cells. Rarely present, umbrella cells were also analysed for the presence of a micronucleus, as they are part of the urothelium and derive from urothelial cells. Some urothelial cells contained one or more cytoplasmic inclusions that could be easily distinguished from a micronucleus since they were not on the same focus plane and were too small (less than 1/16 diameter of the main nucleus). Representative micronucleus (MNu) and cytoplasmic inclusions (stars) present in a urothelial cell analysed at 1000× 
magnification is shown in Figure 1E. The micronuclei frequency per thousand analysed cells for each subject is presented in Table 2. Briefly, we report a mean frequency of $2.6 \pm 1.6 \mathrm{MNu}$ per thousand urothelial cells for females, and $3.0 \pm 1.4$ for male subjects. On the other hand, some blue intermediate squamous cells also presented a micronucleus (Figure $1 \mathrm{~F}$ ), but they were not included in the calculation of the micronuclei frequency in urothelial cells.

\section{Discussion}

The MNu assay was developed in 1982, based on the blood micronucleus (MN) assay (Stich et al., 1982). Since then, many fixation methods have been described, using either methanol alone or Carnoy I fixative before or after cells were spread onto slides. In urine cytology, a 20:1 mix of methanol and acetic acid has also been described as a liquid-based fixative (Koss and Melamed, 2005a). As for staining methods, Feulgen reaction counterstained with Fast green (Moore et al., 1993; Rosin and Anwar, 1992), Diff-Quik (Murray and Edwards, 1999), and Giemsa stain (Ghosh et al., 2006; Gonzalez Cid et al., 1991) are frequently used. Although these staining methods allow for clear demarcation between nucleus and cytoplasm (Majer et al., 2001), distinction between urothelial cells and other cell types present in urine, such as squamous cells, is mainly based on cytological features (Espinoza et al., 2008). Also, some studies report use of fluorescent in situ hybridization with a pancentromeric probe, with propidium iodide as a counterstain, to investigate the content of micronuclei present in urine preparations (Moore et al., 1997b; Warner et al., 1994). However, as urine samples taken from females contain numerous squamous cells from vaginal origin, many population studies have been restricted to males (Burgaz et al., 1995; Moore et al., 1997a; Moore et al., 1997b; Ranmuthugala et al., 2003), therefore limiting their applicability to only a subset of the exposed 
population.

During our optimization process, we combined several approaches taken from medical microbiology, urinary cytology, and the current MNu assay. We improved the technique via a reduced amount of vaginal squamous cells present in urine samples, and a differential staining of urothelial and squamous cells. This was achieved by an extensive washing of the urethral region, including the labiae for women, coupled with a midstream clean catch collection of voided urine specimen, as required for urinary microbiology cultures (Ronald and Alfa, 1996). In addition, the cells were fixed using Carnoy I, which is frequently used in MNu assay, and stained with the multichromatic Papanicolaou technique, as described in urinary cytology (Koss and Melamed, 2005a). This staining technique is used for diagnosis in clinical cytology, as it produces a differential staining allowing for the distinction between cell types present in a variety of biological samples. It had never been used before to perform the MNu assay, probably because development of this assay was based on the blood micronucleus assay, which did not required a differential staining. In clinical settings such as ours, this staining is regularly performed with an automatic slide stainer, but it can be easily realized manually within an hour (Koss and Melamed, 2005a). Even though Papanicolaou technique requires multiple steps when compared to Giemsa staining, its benefits are important as it allowed us to discriminate between urothelial and squamous cells, thus restricting analysis to urothelial cells, even if urine samples of women contained a high proportion of squamous cells, mainly from vaginal origin. Furthermore, the achieved differential staining limits the need for strong urine cytology knowledge, as urothelial cells are small cuboidal cells stained in blue, and most of the squamous cells are large, polygonal and pink. In women's samples, some squamous cells staining in blue were noticed (Figure 1F). These were intermediate squamous cells of vaginal type who were also polygonal, the same size as superficial squamous cells (stained in pink), with their nucleus being slightly larger (Table 1). These characteristics made them easily distinguishable from the smaller cuboidal urothelial cells, even if they 
presented the same blue coloration.

Revision of women's cytology suggested that an additional criterion should be added when selecting women for MNu studies, according to their hormonal status. During days 7 to 13 of the menstrual cycle, the proportion of mature superficial squamous cells present in the vaginal fluid (stained in pink) increases, in comparison to the blue intermediate ones, allowing for an easier discrimination between squamous and urothelial cells. In contrast, following ovulation, intermediate squamous cells (stained in blue) are more numerous in the vaginal fluid (Koss and Melamed, 2005c). On the other hand, particular hormonal conditions present in women, such as breastfeeding period, late post-menopause or some hormone therapies, all characterized by a lack of estrogenic activity, have an influence on the cell composition of the vaginal fluid. During these periods parabasal cells, stained in blue by the Papanicolaou technique, naturally exfoliate (Koss and Melamed, 2005c). Thus, when conducting a population-based study, a special attention should be given to urinary samples from women in the above-mentioned hormonal conditions. These samples should not be included in the MNu study.

Overall, a success rate of $72 \%$ was reached for the isolation and micronuclei analysis of urothelial cells after reception of the first urine specimen of our subjects. Inclusion of the second urine specimen for three subjects raises our success rate to $91 \%$, comparable with the reported success rates achieved on larger population samples (Basu et al., 2004; Fontana et al., 2001). Our analysis also confirmed that women exfoliate more urothelial cells than men. Using this improved technique, we obtained a mean frequency of $2.6 \pm 1.6$ and $3.0 \pm 1.4 \mathrm{MNu} / 1000$ urothelial cells for female and male subjects, respectively. Our values are within the mean frequencies reported for control cohorts in the literature (as reviewed in Table 3). However, a great variation in the $\mathrm{MNu}$ frequencies is reported among these control cohorts, and could be explained by many factors such as sex, age, lifestyle habits, geographic region and ethnicity, sample size, and scoring criteria (Espinoza et al., 2008; Majer et al., 
2001). Nevertheless, we believe that one of the main factors could reside in the ability of the scorers to distinguish correctly between urothelial and squamous cells, during the MNu analysis. As all those control cohorts have no reported diseases, impact of erroneous analysis of a certain number of squamous cells is probably minor. But when monitoring exposed populations, this erroneous distinction could largely influence the results, even more if squamous cells represent a large proportion of cells present in women's urine samples, as noticed in our study and by many authors (Dorrenhaus et al., 2007; Hofseth et al., 1996; Moore et al., 1997a; Stich et al., 1982). For example, given a situation where exposure to a compound did not increase the MN frequency in squamous cells from vaginal origin, but increased it in urothelial cells, erroneous analysis of those squamous cells as part of the MNu assay would lower the resulting MNu frequency and mask a bladder genotoxic effect. The reverse situation could also be encountered and could be more common than previously thought, as even tobacco consumption alone has been associated with an increased MN frequency in exfoliated cells from the cervix (Majer et al., 2001). Since an increased MN frequency will be found in the target cells only when the metabolites reach the epithelia, or when the target cells have sufficient metabolic competence to activate the carcinogen (Majer et al., 2001), a bladder genotoxic substance will be detected if an accurate MNu frequency can be obtained upon analysis of the target cells, namely the urothelial cells.

It is hoped that the improvements proposed in this paper will allow for an easier implementation of the MNu assay in various set-ups and enhance its specificity, since this assay is presently considered a suitable biomarker of bladder cancer risk. As transitional cell carcinoma of the bladder originates from transformed urothelial cells, restricting the micronuclei analysis to urothelial cells could result in a more precise estimate of cancer risk in exposed populations and lead to the implementation of better preventive measures in the living environment and at the workplace. 


\section{Acknowledgements}

The authors wish to thank Dr Claude Viau and Mrs Mélanie Beaulieu Bergeron for the revision of this manuscript, Mrs Josée-Marie Dubé for her assistance in the Papanicolaou technique, and the study subjects for their cooperation. This work was supported by the département de pathologie et biologie cellulaire de l’Université de Montréal [to N.L.], the Fonds de la Recherche en Santé du Québec [to F.F.] and the Fondation de l’Hôpital Sainte-Justine / Fondation des Étoiles [to F.F.]. 


\section{Figure 1}

Representative examples of results obtained with various fixation and staining methods of cells present in voided urine samples, and subsequent identification of micronuclei in squamous and urothelial cells. Urothelial cells (U), vaginal type superficial squamous cells (S), and intermediate squamous cells (I) are marked. (A) Methanol fixation and Giemsa staining of cells. (B) Methanol fixation and Papanicolaou staining. (C) Carnoy I fixation and Giemsa staining. In panels A, B and C, urothelial cells and squamous cells have alike blue or violet coloration. Also, urothelial cells have lost some of their morphological features and nuclei are not clearly delineated. (D), (E) and (F) Carnoy I fixation and Papanicolaou staining of cells. Differential staining of all cell types is achieved, as urothelial cells are blue while superficial squamous cells are red to pink, and intermediate squamous cells are blue. (D) Desmosomal attachment points (small arrows) are clearly visible between urothelial cells. (E) Presence of a micronucleus ( $M N u$ - long arrow), in an urothelial cell. Presence of cytoplasmic inclusions (stars) are also seen in some urothelial cells. (F) Presence of a micronucleus (MN - long arrow) in a blue intermediate squamous cell with glycogen deposits, identifying it as a navicular cell (N). Panels A, B, C and D at original magnification: 400×. Panels E and F at original magnification: $1000 \times$. 

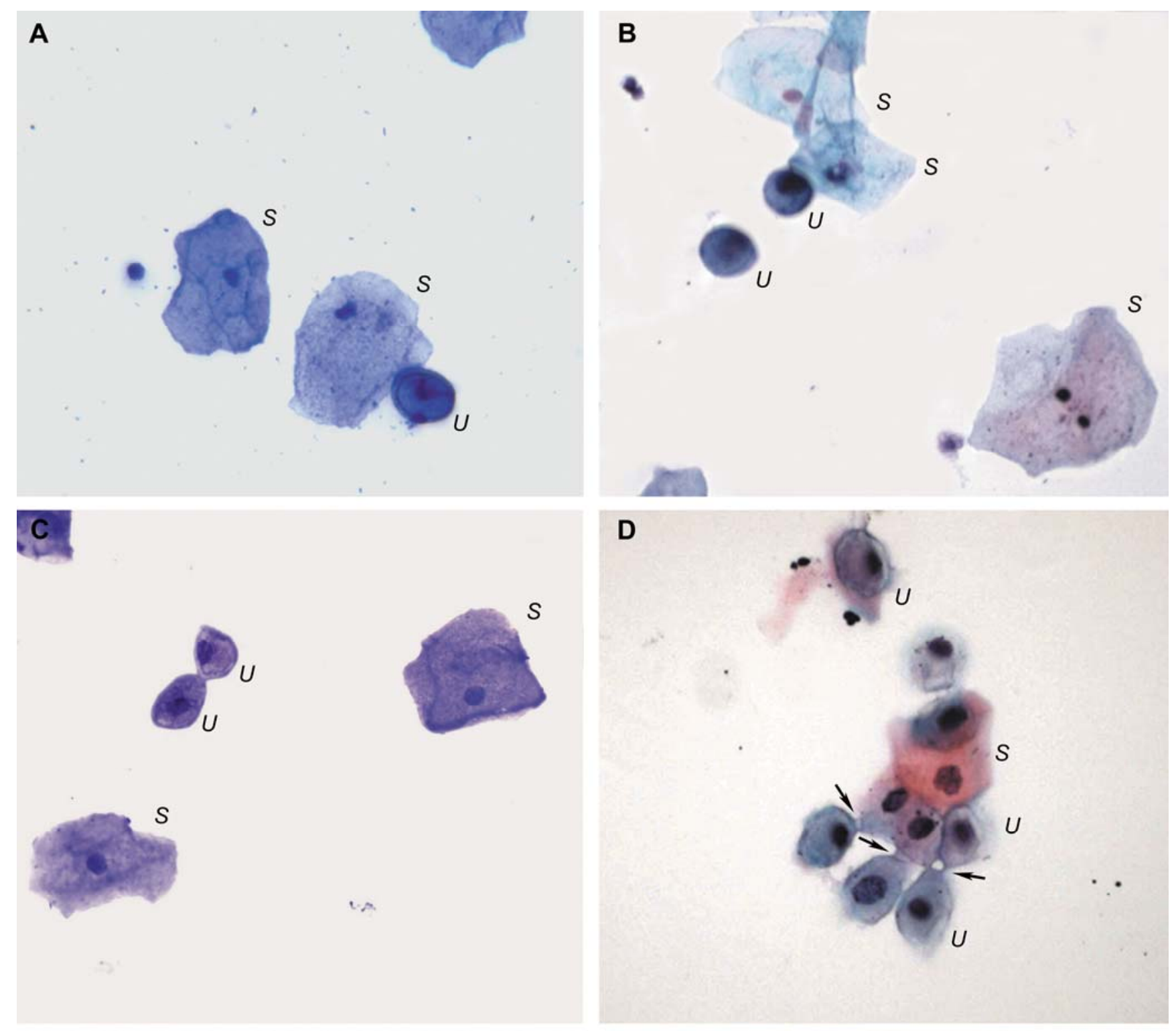

\section{E}
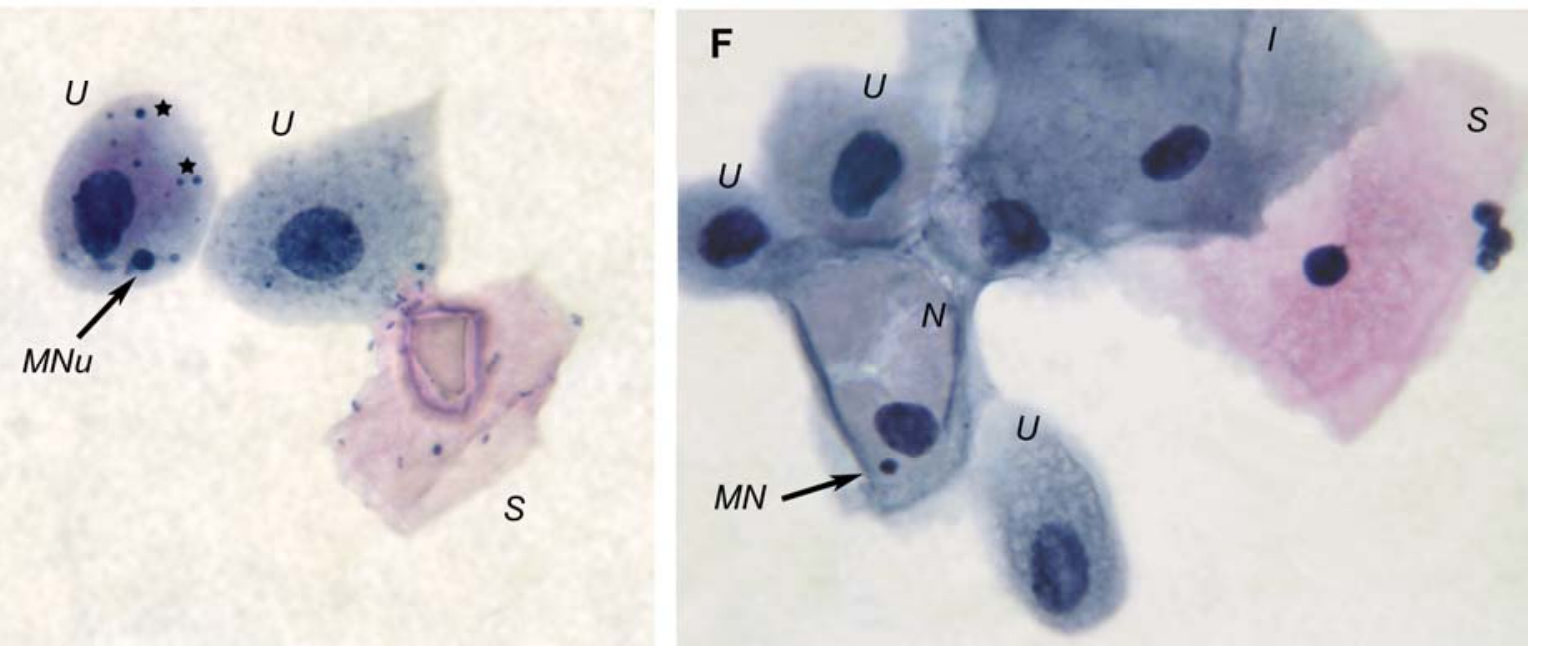

Figure 1 


\section{Table 1}

Main morphological features of urothelial and squamous cells.

\begin{tabular}{llll}
\hline Morphological & Urothelial cells & Superficial & Intermediate \\
features & & squamous cells & squamous cells \\
\hline PAP coloration & Blue & Red to pink & Blue \\
Shape & Cuboidal & Polygonal & Polygonal \\
Relative size & Small cells & Large cells & Large cells \\
Nuclear-cytoplasmic & $1: 2$ to $1: 5$ & $1: 20$ and more & $1: 15$ to $1: 20$ \\
ratio & & & \\
\hline
\end{tabular}




\section{Table 2}

Micronuclei analysis of urothelial cells in 10 subjects. Urine samples were fixed using Carnoy I and differentially stained using the Papanicolaou technique.

Male subjects

\begin{tabular}{ccccc}
\hline \multicolumn{5}{c}{ Female subjects } \\
\hline F1 & F2 $^{\text {a }}$ & F3 & F4 & F5 $^{\text {a }}$ \\
5 & 3 & 3 & 0 & 2 \\
\end{tabular}

One thousand «blue» urothelial cells were analyzed per sample.

${ }^{a}$ Analysis done on the second urinary sample. 


\section{Table 3}

Reported urinary micronuclei frequencies (per 1000 analyzed cells) in control (unexposed) subjects.

\begin{tabular}{|c|c|c|c|}
\hline Sex & $\begin{array}{l}\text { Urinary micronuclei frequency } \pm \\
\text { Standard deviation }\end{array}$ & $\begin{array}{l}\text { Number of } \\
\text { subjects }\end{array}$ & References \\
\hline $\mathrm{nr}$ & $0.62 \pm 0.52 \%^{a}$ & $\mathrm{nr}$ & Moore et al., 1993 \\
\hline$M+F$ & $0.53 \pm 0.14 \%^{a}$ & 13 & Tian et al., 2001 \\
\hline$M+F$ & $0.56 \pm 0.45 \%{ }^{a}$ & 21 & Basu et al., 2002 \\
\hline$M+F$ & $2.73 \pm 0.59 \%^{a}$ & 10 & Jen et al., 2002 \\
\hline Males & $0-20 \%{ }^{b}$ & 30 & Kassie et al., 2001 \\
\hline Males & $7.3 \pm 1.8 \%$ & 15 & Gonzalez Cid et al., 1991 \\
\hline Males & $1.2 \pm 0.4 \%$ о & 32 & Rosin and Anwar, 1992 \\
\hline Males & $2.14 \pm 0.46 \%$ & 8 & Warner et al., 1994 \\
\hline Males & $6.6 \pm 0.5 \%$ & 20 & Burgaz et al., 1995 \\
\hline Males & $0.98 \pm 0.3 \%$ & 26 & Hofseth et al., 1996 \\
\hline Males & $1.6 \%$ & 19 & Moore et al., 1997b \\
\hline Males & $1.7 \%$ & 85 & Ranmuthugala et al., 2003 \\
\hline Males & $1.36 \pm 0.041 \%$ & 88 & Basu et al., 2004 \\
\hline Males & $6.88 \pm 0.18 \%$ о & 18 & Murray and Edwards, 2005 \\
\hline Males & $3.0 \pm 1.4 \%$ & 5 & Present study \\
\hline \multicolumn{4}{|c|}{ Mean Mnu frequency in males $\quad 3.28 \%$} \\
\hline Females & $0.83 \pm 0.74 \%$ о & 5 & Titenko-Holland et al., 1994 \\
\hline Females & $1.28 \pm 0.31 \%$ о & 10 & Warner et al., 1994 \\
\hline Females & $4.7 \pm 3.1 \%$ & 4 & Lehucher-Michel et al., 1996 \\
\hline Females & $1.4 \pm 0.3 \%$ & 41 & Fontana et al., 2001 \\
\hline Females & $1.48 \pm 0.051 \%$ & 66 & Basu et al., 2004 \\
\hline
\end{tabular}




$\begin{array}{llll}\text { Females } & 9.72 \pm 0.82 \% \text { o } & 72 & \text { Espinoza et al., } 2008 \\ \text { Females } & 2.6 \pm 1.6 \% & 5 & \text { Present study }\end{array}$

Mean MNu frequency in females $3.14 \%$

nr: not reported

M + F: Males and Females - grouped results

${ }^{a}$ Values excluded for the calculation of the mean $\mathrm{MNu}$ frequencies, because both sexes were paired or not reported.

${ }^{\mathrm{b}}$ Value excluded for the calculation of the mean $\mathrm{MNu}$ frequency in males, because a frequency interval was given. 


\section{References}

Barcia, J. J., 2007. The Giemsa stain: its history and applications. Int. J. Surg. Pathol. 15, 292-296.

Basu, A., Ghosh, P., Das, J.K., Banerjee, A., Ray, K., Giri, A.K., 2004. Micronuclei as biomarkers of carcinogen exposure in populations exposed to arsenic through drinking water in West Bengal, India: a comparative study in three cell types. Cancer Epidemiol. Biomarkers Prev. 13, 820-827.

Basu, A., Mahata, J., Roy, A.K., Sarkar, J.N., Poddar, G., Nandy, A.K., Sarkar, P.K., Dutta, P.K., Banerjee, A., Das, M., Ray, K., Roychaudhury, S., Natarajan, A.T., Nilsson, R., Giri, A.K., 2002. Enhanced frequency of micronuclei in individuals exposed to arsenic through drinking water in West Bengal, India. Mutat. Res. 516, 29-40.

Biggs, M.L., Kalman, D.A., Moore, L.E., Hopenhayn-Rich, C., Smith, M.T., Smith, A.H., 1997. Relationship of urinary arsenic to intake estimates and a biomarker of effect, bladder cell micronuclei. Mutat. Res. 386, 185-195.

Burgaz, S., Iscan, A., Buyukbingol, Z.K., Bozkurt, A., Karakaya, A.E., 1995. Evaluation of micronuclei in exfoliated urothelial cells and urinary thioether excretion of smokers. Mutat. Res. 335, 163-169.

DeMarini, D.M., 2004. Genotoxicity of tobacco smoke and tobacco smoke condensate: a review. Mutat. Res. 567, 447-474.

Dorrenhaus, A., Muller, T., Roos, P.H., 2007,). Increased CYP1A1 expression in human exfoliated urothelial cells of cigarette smokers compared to non-smokers. Arch. Toxicol. 81, 19-25.

Espinoza, F., Silverman, D., Kogevinas, M., Creus, A., Fernandez, F., Garcia-Closas, M., Tardon, A., Garcia-Closas, R., Serra, C., Carrato, A., Rothman, N., Dosemeci, M., Malats, N., Marcos, R., 2008. Micronuclei assessment in the urothelial cells of women using hair dyes and its modulation by genetic polymorphisms. Cancer Lett. 263, 259-266.

Fenech, M., 2007. Cytokinesis-block micronucleus cytome assay. Nature Protocols 2, 1084-1104. Fontana, L., Lasfargues, G., Ughetto, S., Rogier, S., Masdieu, E., Lafaure, M., Aublet-Cuvelier, B., and Catilina, P., 2001. The micronucleus assay in human exfoliated urothelial cells: application in a genotoxicity study of workers exposed to a mineral jelly containing sodium nitrite and $\mathrm{N}$ phenyl-1-naphthylamine. Mutagenesis 16, 449-452.

Ghosh, P., Basu, A., Mahata, J., Basu, S., Sengupta, M., Das, J.K., Mukherjee, A., Sarkar, A.K., Mondal, L., Ray, K., Giri, A.K., 2006. Cytogenetic damage and genetic variants in the individuals susceptible to arsenic-induced cancer through drinking water. Int. J. Cancer 118, 
2470-2478.

Gonzalez Cid, M., Loria, D., Vilensky, M., Miotti, J.L., Matos, E., 1991. Leather tanning workers: chromosomal aberrations in peripheral lymphocytes and micronuclei in exfoliated cells in urine. Mutat. Res. 259, 197-201.

Hofseth, L.J., Dunn, B.P., Rosin, M.P., 1996. Micronucleus frequencies in urothelial cells of catheterized patients with chronic bladder inflammation. Mutat. Res. 352, 65-72.

Jen, M.H., Hwang, J.J., Yang, J.Y., Nabyvanets, Y.B., Hsieh, W.A., Tsai, M.H., Guo, S.D., Chang, W.P., 2002. Micronuclei and nuclear anomalies in urinary exfoliated cells of subjects in radionuclide-contaminated regions. Mutat. Res. 520, 39-46.

Kassie, F., Darroudi, F., Kundi, M., Schulte-Hermann, R., Knasmuller, S., 2001. Khat (Catha edulis) consumption causes genotoxic effects in humans. Int. J. Cancer 92, 329-332.

Koss, L.G., Melamed, M.R. 2005a. Laboratory techniques, in Koss, L.G., Melamed, M.R. (Eds.), Koss' Diagnostic Cytology and its Histopathologic Bases, 5th ed. Lippincott Williams \& Wilkins, Philadelphia, pp. 1569-1635.

Koss, L.G., Melamed, M.R. 2005b. The lower urinary tract in the absence of cancer, in Koss, L.G., Melamed, M.R. (Eds.), Koss' Diagnostic Cytology and its Histopathologic Bases, 5th ed. Lippincott Williams \& Wilkins, Philadelphia, pp. 738-771.

Koss, L. G., and Melamed, M. R. (2005c). The normal female genital tract, in Koss, L.G., Melamed, M.R. (Eds.), Koss' Diagnostic Cytology and its Histopathologic Bases, 5th ed. Lippincott Williams \& Wilkins, Philadelphia, pp. 183-226.

Koss, L. G., and Melamed, M. R. (2005d). Tumors of the urinary tract in urine and brushings, in Koss, L.G., Melamed, M.R. (Eds.), Koss' Diagnostic Cytology and its Histopathologic Bases, 5th ed. Lippincott Williams \& Wilkins, Philadelphia, pp. 777-846.

Lehucher-Michel, M. P., Amara-Mokrane, Y. A., Devictor, B., Catilina, P., and Botta, A. (1996). Micronuclei kinetics of exfoliated urothelial cells. Mutat. Res. 354, 1-7.

Majer, B.J., Laky, B., Knasmuller, S., Kassie, F., 2001. Use of the micronucleus assay with exfoliated epithelial cells as a biomarker for monitoring individuals at elevated risk of genetic damage and in chemoprevention trials. Mutat. Res. 489, 147-172.

McKee, G.T., 2003. Urinary tract cytology, in Gray, W. McKee, G.T. (Eds.), Diagnostic Cytopathology, 2nd ed. Churchill Livingstone, London, pp. 471-498.

Moore, L.E., Smith, A.H., Hopenhayn-Rich, C., Biggs, M.L., Kalman, D.A., Smith, M.T., 1997a. Decrease in bladder cell micronucleus prevalence after intervention to lower the concentration of 
arsenic in drinking water. Cancer Epidemiol. Biomarkers Prev. 6, 1051-1056.

Moore, L.E., Smith, A.H., Hopenhayn-Rich, C., Biggs, M.L., Kalman, D.A., Smith, M.T., 1997b. Micronuclei in exfoliated bladder cells among individuals chronically exposed to arsenic in drinking water. Cancer Epidemiol. Biomarkers Prev. 6, 31-36.

Moore, L E., Titenko-Holland, N., Quintana, P.J., Smith, M.T., 1993. Novel biomarkers of genetic damage in humans: use of fluorescence in situ hybridization to detect aneuploidy and micronuclei in exfoliated cells. J. Toxicol. Environ. Health 40, 349-357.

Murray, E.B., Edwards, J.W., 1999. Micronuclei in peripheral lymphocytes and exfoliated urothelial cells of workers exposed to 4,4'-methylenebis-(2-chloroaniline) (MOCA). Mutat. Res. 446, 175180.

Murray, E.B., Edwards, J.W., 2005. Differential induction of micronuclei in peripheral lymphocytes and exfoliated urothelial cells of workers exposed to 4,4'-methylenebis-(2-chloroaniline) (MOCA) and bitumen fumes. Rev. Environ. Health 20, 163-176.

Ranmuthugala, G., Pilotto, L., Smith, W., Vimalasiri, T., Dear, K., Douglas, R., 2003. Chlorinated drinking water and micronuclei in urinary bladder epithelial cells. Epidemiology 14, 617-622.

Reali, D., Di Marino, F., Bahramandpour, S., Carducci, A., Barale, R., Loprieno, N., 1987. Micronuclei in exfoliated urothelial cells and urine mutagenicity in smokers. Mutat. Res. 192, 145-149.

Ronald, A.R., Alfa, M.J., 1996. Microbiology of the genitourinary system, in Baron, S. (Ed), Medical Microbiology, 4th ed. The University of Texas Medical Branch at Galveston, Galveston, pp. 1143-1157.

Rosin, M.P., Anwar, W., 1992. Chromosomal damage in urothelial cells from Egyptians with chronic Schistosoma haematobium infections. Int. J. Cancer 50, 539-543.

Stich, H.F., Curtis, J.R., Parida, B.B., 1982,). Application of the micronucleus test to exfoliated cells of high cancer risk groups: tobacco chewers. Int. J. Cancer 30, 553-559.

Straif, K., Baan, R., Grosse, Y., Secretan, B., El Ghissassi, F., Bouvard, V., Altieri, A., BenbrahimTallaa, L., Cogliano, V., 2007. Carcinogenicity of shift-work, painting, and fire-fighting. Lancet Oncology 8, 1065-1066.

Straif, K., Baan, R., Grosse, Y., Secretan, B., El Ghissassi, F., Cogliano, V., 2005. Carcinogenicity of polycyclic aromatic hydrocarbons. Lancet Oncology 6, 931-932.

Tian, D., Ma, H., Feng, Z., Xia, Y., Le, X.C., Ni, Z., Allen, J., Collins, B., Schreinemachers, D., Mumford, J.L., 2001,). Analyses of micronuclei in exfoliated epithelial cells from individuals 
chronically exposed to arsenic via drinking water in inner Mongolia, China. J Toxicol Environ Health A 64, 473-484.

Titenko-Holland, N., Moore, L.E., Smith, M.T., 1994. Measurement and characterization of micronuclei in exfoliated human cells by fluorescence in situ hybridization with a centromeric probe. Mutat. Res. 312, 39-50.

van Delft, J.H., Steenwinkel, M.S., van Asten, J.G., de Vogel, N., Bruijntjes-Rozier, T.C., Schouten, T., Cramers, P., Maas, L., van Herwijnen, M.H., van Schooten, F., Hopmans, P.M., 2001,). Biological monitoring the exposure to polycyclic aromatic hydrocarbons of coke oven workers in relation to smoking and genetic polymorphisms for GSTM1 and GSTT1. Ann. Occup. Hyg. 45, 395-408.

Warner, M.L., Moore, L.E., Smith, M.T., Kalman, D.A., Fanning, E., Smith, A.H., 1994. Increased micronuclei in exfoliated bladder cells of individuals who chronically ingest arseniccontaminated water in Nevada. Cancer Epidemiol. Biomarkers Prev. 3, 583-590. 